International Journal of Linguistics, Literature and Culture
Available online at https://sloap.org/journals/index.php/ijllc/
Vol. 5, No. 1, January 2019, pages: $24 \sim 31$
ISSN: $2455-8028$
https://doi.org/10.21744/ijllc.v5n1.478

\title{
Spirit of Nationalism, Education and Moral Religion: Nation Character Building Portrayed in Si Bulus-Bulus Si Rumbuk-Rumbuk Written by Willem Iskander
}

Siti Norma Nasution ${ }^{\text {a }}$

Article history:

Received: 27 July 2018

Accepted: 30 November 2018

Published: 19 December 2018

\section{Keywords:}

character building;

education:

moral religion;

nationalism;

preservation of culture;

\begin{abstract}
This paper is written based on the research entitled "Semangat Kebangsaan, Pendidikan Dan Moral Agama Yang Membangun Karakter Bangsa Dalam Si Bulus-Bulus Si Rumbuk-Rumbuk Karya Willem Iskander" (The Spirit of Nationalism, Education and Moral Religion as Nation Character Building Which Portrayed in Si Bulus-Bulus Si Rumbuk-Rumbuk Written By Willem Iskander). There are two problems have been analyzed, the first one is to expose the ideas contained in the poems. The second problem is the analyses of idea have influenced the development of social and economic welfare of the society. The special purpose of this research is to anticipate the negative impact of global chaos for the young generation. They are expected not to be uprooted from their tradition and culture. Local wisdom as a part of the philosophy of life should be preserved as our national asset for our better future. There are at least thirty persons have been interviewed. They are the local leaders for religion, education, and social activities. The method used is descriptive qualitative. The data are collected by using the recorded technique, documentation of photos. The theory used hermeneutic, sociology of literature and the theory of culture. The result of this research showed that most of the young generation didn't know about poems because they didn't get it from school. Some of them knew from elder family or from the local library. The team of the researcher recommended the local authorities, the students are given or taught the local language and literature especially for a junior and senior high school in Muarasoma Residences, South Tapanuli.
\end{abstract}

2455-8028 ${ }^{\circledR}$ Copyright 2019. The Author. This is an open-access article under the CC BY-SA license (https://creativecommons.org/licenses/by-sa/4.0/) All rights reserved.

\section{Author correspondence:}

Siti Norma Nasution,

English Literary Studies Program, Faculty of Cultural Science, University of North Sumatera,

Medan, Indonesia

Email address: sitinorma.nasution@yahoo.com

${ }^{a}$ Faculty of Cultural Science, University of North Sumatera, Medan, Indonesia 


\title{
1. Introduction
}

Si Bulus-Bulus Si Rumbuk-Rumbuk was written By Willem Iskander living in 1840-1876 when the Indonesian nation was under Dutch colonialization. The collection of poems were written in local language that is Mandailing language. So, it can be regarded as local literature but the theme and the messages showed the spirit of nationalism and strong unity. This is the greatness of Willem Iskander, he did not talk about the local problems anymore but focus on the problems of independence and nationalism. Birch, D. (2005), the poems were expressed in the local language to hinder the colonial attention to the people's movement. Through his poems, Willem Iskander encouraged the people to fight for national independence, to repel the colonialists from this beloved country. This idea can be seen in this poem.

\author{
Adong alak ruar (There were foreigners) \\ Na mian di Panyabungan (Who lived in Panyabungan) \\ Tibu ia aruar (They should be discharged) \\ Baon ia madung busungan (They had been full) \\ (Harahap, 1998, Willem Iskander Si Bulus-Bulus Si Rumbuk-Rumbuk, p. 25.)
}

Based on the description above, the researcher may consider that Willem Iskander ideas and thoughts are still relevant to be discussed and analyzed in this global era (at the present time). The spirit of nationhood and nationalism should be revitalized especially for the young generation who got influences and the negative impact from the western culture through the rapid improvement of knowledge and technology.

The theme and the messages exposed in Si Bulus-Bulus Si Rumbuk-Rumbuk can be considered as the solution for the problems we are facing nowadays. Willem Iskander had told about education, nationalism and moral, religious teachings a century ago. In this global era, our country is still facing the complicated problems to be solved. This research focused on the social function of a literary work especially when the work exposed about the institution of the society such as religion, education, tradition and culture, ideology and nationalism. The development of the social economy of Mandailing ethnic group might have been influenced by the ideas and thoughts of Willem Iskander which are expressed in Si Bulus-Bulus Si Rumbuk-Rumbuk.

In this global era, Willem Iskander's ideas and thoughts are still relevant to be adopted to reach nation character building for the young generation to anticipate the negative impacts from the western culture. The winning of capitalism had changed the people's lifestyle, they tended to be a hedonist, consumerist and materialist over then made global chaos, because people claimed that they are right although they may humiliate other people. In the field research the group discussion continued to answer the questions made by the team, the informants (teachers) also asked the questions to know more about Willem Iskander and his poems. It was quite surprising to know that only elder teachers knew about Willem Iskander and his poems. There are only about ten teachers (Up to sixty years old) knew about Willem Iskander because they got it from schools or from their parents and society.

From the field research, it was found out that most of the informants did not know about because they did not have the book in the library. From thirty teachers who were interviewed, there were only ten teachers knew about Willem Iskander and the poems. They knew and got the subject from school or informed by elder people around them. From the information, it was known that after 1960 the students in Muarasoma and Tanobato didn't study about Willem Iskander and the poems. All the teachers agreed if the subject about Willem Iskander and his poems would be given for the students as the local contents in the school curriculum, the students should study about their local language, culture, and tradition. The team had sent thirty copies book about Willem Iskander and the poems after returned to Medan (USU).

At the present time, the students should follow the curriculum in 1994, no local language was given, only some folklore from other places were discussed. During the interview, most of the teachers agreed that Willem Iskander and the poems should be given to the students in Muarasoma and Tanobato. Willem Iskander is so popular in academic issue but he is forgotten in the place where he was born. One hundred years before Indonesian independence, Willem Iskander had thought about nationalism, education, and people's welfare especially for the people around him. He taught for his country by using pen not by using a weapon like other national heroes who repel the colonial to get independence.

Willem Iskander had risen the spirit of the local leaders to think about the unity and nationalism as expressed in this quotation. Si Bulus-Bulus Si Rumbuk-Rumbuk had inspired the next generation after the period of Willem Iskander it can be seen from the history of the movement in the South Tapanuli (Harahap, 1998, Willem Iskander Si Bulus-Bulus Si Rumbuk-Rumbuk, p. 7.)

Nasution, S. N. (2018). Spirit of nationalism, education and moral religion. International Journal of Linguistics, Literature and Culture, 5(1), 24-31. https://doi.org/10.21744/ijllc.v5n1.478 
His special attention to education showed how his ideas and thoughts. At the time the Dutch colonialists forbade the people to read and write, people only can speak in their local languages. Getting knowledge through education would open and enlarge the people's thoughts and later claimed for freedom, independence, and human rights, equal rights for all people in the world (Ratna, 2004; Sibarani, 2012).

Willem Iskander thought that education is the prime way to leave poverty and backwardness. He strongly advised young generation to go to school to get the education through this poem.

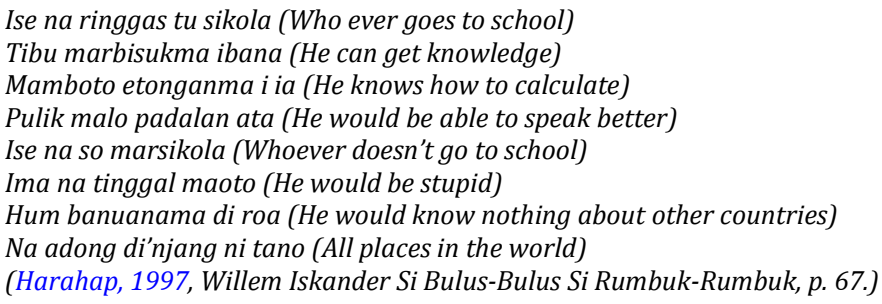

Willem Iskander also exposed the urgent of planting moral and religious values, especially for the young generation as portrayed in the following poems.

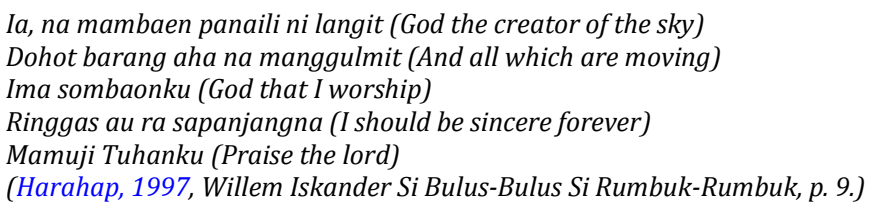

\section{Materials and Methods}

This research is made based on library and field research. The data are taken from the text of the poems Si BulusBulus Si Rumbuk-Rumbuk. Supporting data are taken from any book and information written by people about Willem Iskander and the poems. In the field research, there are more than thirty people interviewed individually and in Focus Group Discussion (FGD). The informants are mostly the teachers in three schools in Muarasoma and Tanobato as the location of this research because Tanobato is the place where Willem Iskander was born and established his first school. The theory of literature and culture is used to analyze the poems to get the total meaning (Miles \& Huberman, 1984; Batool et al., 2014).

\section{Results and Discussions}

The team of researchers decided to go to three schools to interview the teachers in groups (Focus Group Discussion). From the interview in three schools in Muarasoma, the team of researchers found out that only the teachers up to sixty years still knew about the poems Si Bulus-Bulus Si Rumbuk-Rumbuk. These old teachers studied the poems when they were still students in Muarasoma. In one school there are ten teachers asked for discussion, the team asked ten questions to be answered then after that there happened two ways communication, the teachers asked some questions about Si Bulus-Bulus Si Rumbuk-Rumbuk and the purpose of the team to conduct this research. The team answered that Willem Iskander is now so popular in Universities, Basral Hamidy Harahap from Indonesian University even went to Holland in to make a research about life story (biography) of Willem Iskander. He was so interested in the history of Willem Iskander and the friends, especially for establishing of local schools in his hometown in Tanobato Muarasoma. Harahap had translated the poems Si Bulus-Bulus Si Rumbuk-Rumbuk into Bahasa Indonesia because the poems were written by Willem Iskander in Mandailing Language.

In the University of North Sumatra, there are some students and lectures had analyzed about the poems, one of whom is Lubis (2007), for his thesis in Indonesian Language Department, Faculty of Cultural Sciences. The head of the team, Nasution also discussed the poems Si Bulus-Bulus Si Rumbuk-Rumbuk for the students of English Department for the subject of Theory of Literature. To explain Sociology of Literature, Nasution discussed the elements and institution in society such as education, religion, and moral teachings. So, when the team conducted the 
field research in Muarasoma, it was quite surprising to find out that only some of the teachers still knew about the poems (Leech, 2014).

What a pity to know that in Muarasoma where Willem Iskander was born and established his first local school, there was almost nobody remembered him and his poems. Even in the library of the schools, they didn't keep any book about Willem Iskander and the poems Si Bulus-Bulus Si Rumbuk-Rumbuk. Finding the realities like this, the team decided to send the copies of the poems to the three schools in Muarasoma.

People in Tanobato and Muarasoma also cared about the youth education, that's why they help and support Willem Iskander to open the first school in Tanobato called Kweekschool for the native people. Poems about education are the most popular in Si Bulus-Bulus Si Rumbuk-Rumbuk. Willem Iskander strongly emphasized the youth not to be lazy to improve their knowledge and skill, if they wanted to reach the bright future. During the struggle, the youth should be strong experiencing living in miseries and backwardness should sacrificed their time for better future.

The following poems showed us Willem Iskander ideas for education.

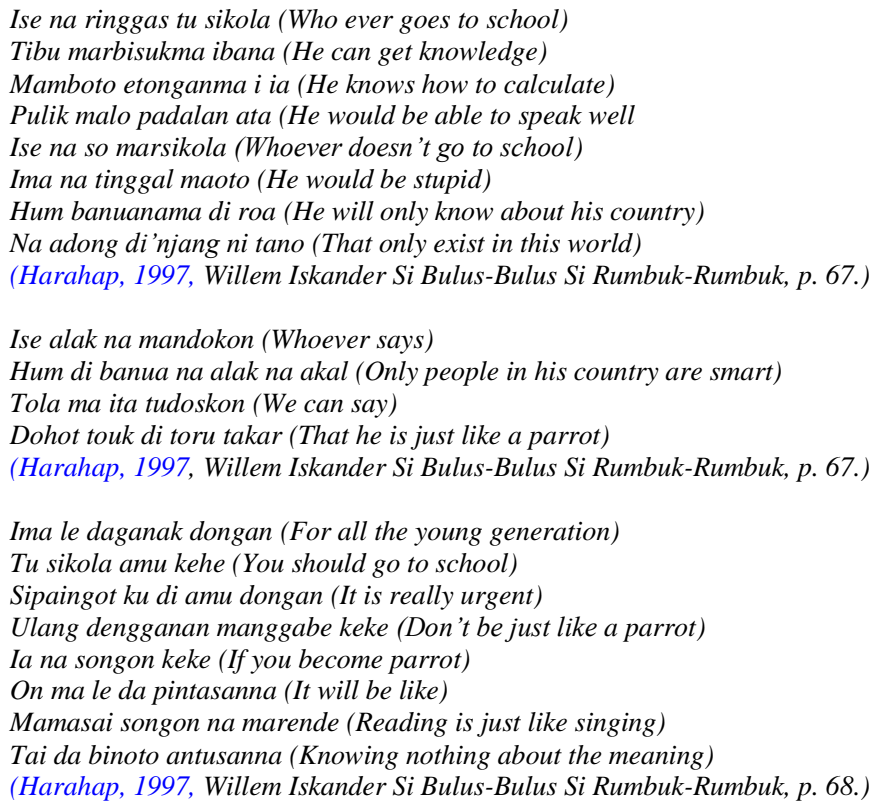

Advice from Father to the Son

Labo ale amang sinuan tunas (Oh my beloved son)

Langka ma ho amang marguru tu sikola (You should go to school to study)

Ulang hum baen songon luas-luas (Don't go to have fun)

Tai ringgas ko amang marsipoda (But to study hard to get knowledge)

Anggo panganon dohot abit (I'll try hard to fulfil your needs)

Uparkancitkon manjalaisa (I'll provide your food and cloth)

Inda au nian makikit, dio mangalehensa (I'll give all your necessities)

Muda langka au manjala (When I go fishing)

Dapot au dua mera (I get two big fishes)

Ugadisma i sada (The one will be sold)

Anso adong dio panabusi sira (To provide for your needs)

Dapot au dohot inangmu (I and your mother)

Muda adong tuor ni kopi (When Harvesting coffee from ourfield)

Deba do i upajopi (I'll keep some profit)

Deba ambaen dio abit matomu (And the rest is for your future)

Imale nian amang (Oh my beloved son)

Por ni roangku ho marbisuk (I hope you to be smart)

Ampot sogot madok-dokma ulala pamatang (When I become old)

Anso ho doma ubaen usuk (I hope you will be my the backbone)

(Harahap, 1997, Willem Iskander Si Bulus-Bulus Si Rumbuk-Rumbuk, p. 69.)

Nasution, S. N. (2018). Spirit of nationalism, education and moral religion. International Journal of 


\section{The spirit of nationalism}

When Si Bulus-Bulus Si Rumbuk-Rumbuk was written, Indonesia was still in Dutch colonialization, people lived in poverty and misery. Willem Iskander expressed his anger through his poems to repel the colonialist from this beloved country, he said, there were foreigners who were full enough robing our natural resources. Through his poem entitled Mandailing, he inculcated the spirit of nationalism, the struggle for independence. Willem Iskander tried hard to burn the spirit of freedom, to get the basic rights for humans to pursue happiness for life. This is the poem.

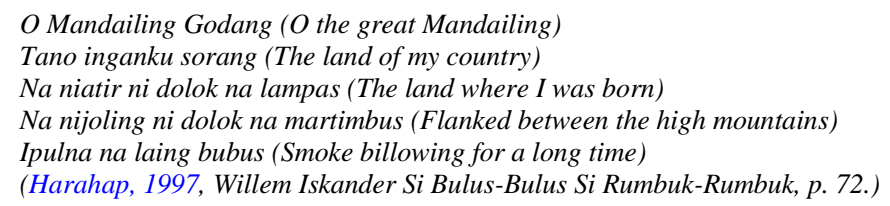

The collection of these poems showed the beauty of Mandailing land with the clean rivers, mountains and fertile land to grow rice. Our land is really rich with natural resources to become a great country. Implicitly in the local language, Willem Iskander encouraged the local leaders for our independence. In fact that it was quite successful to use this poem to spread the spirit to fight against the imperialist. A local leader like Buyung Siregar and the group were sent to prison in Digul by Dutch government because evidence against the colonial government. At the same time, Si Bulus-Bulus Si Rumbuk-Rumbuk was forbidden to read, people may have the book secretly.

The spirit of nationalism was also exposed in the poem Marburu Di Bagasan Bilik (Hunting in his own room). This poem is still relevant to be discussed the present time because it talked about a corrupt leader who lived comfortably by accepting bribery from the Dutch government, he spent the money dissipated until one day he realized that he fell bankrupt. He was isolated from the social life because of his bad behaviour and attitude. He was living alone without power, dominated by the Dutch Colonialist.

\section{Education}

The focus of Willem Iskander's struggle is education because, during Dutch colonialization, it was forbidden for Bumiputera (native people) to learn reading and writing. It was a threat to the colonial if the native people get knowledge from reading some books. It might open their mind about freedom and basic rights for a human. Willem Iskander really understood about this. In pengajian (local meeting) people communicate in Arabic an local language, they learn the teaching of Al-Qur'an and Hadist.

They discussed the local problems and the solution. How to manage Lubuk Larangan (growing and keeping the local fishes) to build a small mosque and open new roads to the newly established villages. The Indonesian language is known as Melayu Language. There were only a few people spoke this language (the people who got experiences working outside Muarasoma and Panyabungan. Willem Iskander suggested the young generation strongly to go to school to study reading, writing, mathematics and other knowledge. Education is the prime way to leave poverty and stupidity. The students may learn about the history of other countries to compare and to adopt the policy and management to improve their local condition. One of the local wisdom of the society is helping and caring for each other, they regard themselves as a big family. In the Mandailing ethnic group, there is a family system called Dalihan Natolu, they are Mora, Kahanggi, and Anak Boru, which have different function and responsibility within their society. Mora is the prime group who are responsible to manage and care for the social activities of the big family. Kahanggi is just like the brother of Mora who agreed and followed Mora's advice and suggestions. The third one is called Anak Boru who executed all the works and activities of one event.

\section{Religion}

The Other theme exposed in Si Bulus-Bulus Si Rumbuk-Rumbuk is about religion. Willem Iskander emphasized the greatness of the Creator that is God for all human beings. God may bless people who obey religious teachings. People should pray to God and do not break the law of religion. Human beings are considered so small compared to the greatness of the creator. 
The poems about religion are as follows.

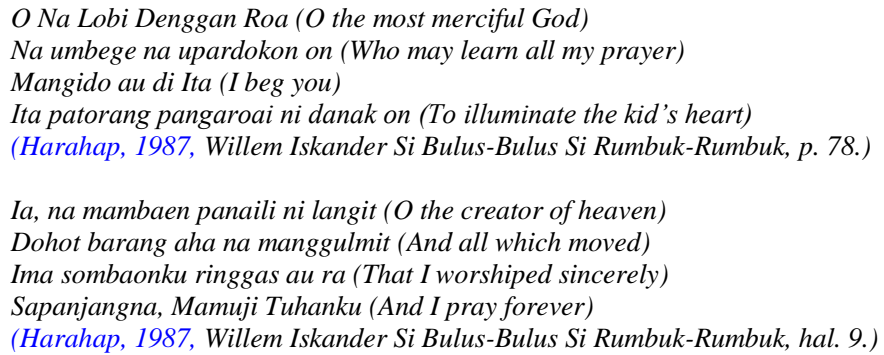

\section{Conclusion}

From the analyses, it is found out that there are three valuable ideas portrayed in Si Bulus-Bulus Si RumbukRumbuk, they are education, religion, and the spirit of nationalism. These three points are still relevant to be discussed in this global era because Indonesia is still facing the complicated problems to be solved. For the young generation, these ideas can be made as anticipation of the negative impact of western culture and imperialism.

The ideas and thoughts of Willem Iskander had motivated people in Muarasoma and Tanobato and the readers to reach the success in society and economy. Willem Iskander ideas and thoughts can be made the character building, especially for the young generation.

The model or strategy is made in the form of recommendation for the local authority to give the students the subjects of Willem Iskander and the poems to be studied in schools. The books about Willem Iskander and the poems had been distributed to the schools in Muarasoma and Tanobato.

Conflict of interest statement and funding sources

The author declared that no competing interest. The study was financed by TALENTA as a research program in USU.

Statement of authorship

The author has a responsibility for the conception and design of the study. The author has approved the final article.

\section{Acknowledgments}

First of all, I would like to give my appreciation the rector of University of North Sumatera (USU) who had given the chance for the lecturers to follow TALENTA as a research program in USU and providing the fund for this research. I would also give my gratitude the head of Research Institution in USU that had tried hard to encourage the lecturers to conduct research provided in Talenta. Then would thank all the officials in research institution who had helped all the lecturers to accomplished the research by giving information, the model and the form of research, that the researchers needed.

Nasution, S. N. (2018). Spirit of nationalism, education and moral religion. International Journal of 


\section{References}

Ardi, A. (2013). Willem Iskander (1840-1876) Pelopor Pendidikan Di Mandailing Sumatra Utara (Doctoral dissertation, UNY).

Batool, S., Khan, A. B., Iqbal, A., Ali, K., \& Rfiq, R. M. H. (2014). Stylistic Analysis of Robert Frost's Poem:“The Road Not Taken". Journal of ELT and Applied Linguistics (JELTAL), 2(4), 52-64.

Birch, D. (2005). Language, literature and critical practice: Ways of analysing text. Routledge.

Harahap, B.H. (1987). Willem Iskander Si Bulus-Bulus Si Rumbuk-Rumbuk. Jakarta: Puisi Indonesia.

Harahap, B.H. (1998). Sati Gelar Sutan Iskandar Alias Willem Iskander (1840 - 1876). Medan: Tanpa Penerbit.

Leech, G. N. (2014). A linguistic guide to English poetry. Routledge.

Lubis, H. S. (2007). Modernisasi Pada Bentuk Dan Tema Dalam Prosa-Prosa Willem Iskander (18401876). Modernisasi Pada Bentuk Dan Tema Dalam Prosa-Prosa Willem Iskander (1840-1876).

Miles, M. B., \& Huberman, A. M. (1984). Qualitative data analysis: A sourcebook of new methods. In Qualitative data analysis: a sourcebook of new methods. Sage publications.

Ratna, N. K. (2004). Teori, Metode, dan Teknik Penelitian Sastra dari Strukturalisme hingga Poststrukturalisme Perspektif Wacana Naratif. Yogyakarta: Pustaka Pelajar.

Sibarani, R. (2012). Kearifan Lokal: Hakikat, Peran, dan Metode Tradisi Lisan. Asosiasi Tradisi Lisan (ATL). 


\section{Biography of Author}

\begin{tabular}{||l|l||}
\hline & $\begin{array}{l}\text { Dr. Siti Norma Nasution, M. Hum. Graduated her bachelor degree in the Faculty of Literature in } \\
\text { University Of North Sumatera (1982). She finished her master degree in Humaniora Magister } \\
\text { Program, American Studies Program in University of Gadjah Mada (1994). She completed her } \\
\text { doctoral degree in Literature Studies of Doctoral Program in University of Udayana (2012). } \\
\text { Email: sitinorma.nasution@yahoo.com }\end{array}$ \\
\hline
\end{tabular}

Nasution, S. N. (2018). Spirit of nationalism, education and moral religion. International Journal of Linguistics, Literature and Culture, 5(1), 24-31. https://doi.org/10.21744/ijllc.v5n1.478 